Marquette University

e-Publications@Marquette

Clinical Lab Sciences Faculty Research and

Publications

Health Sciences, College of

6-1-2011

Prevalence of Myxobolus cerebralis Infections Among Genetic Lineages of Tubifex tubifex at Three Locations in the Madison River, Montana

\author{
Nilanjan Lodh \\ Marquette University, nilanjan.lodh@marquette.edu \\ Lori Stevens \\ University of Vermont \\ Billie Kerans \\ Montana State University - Bozeman
}

Accepted version. Journal of Parasitology, Vol. 97, No. 3 (June 2011): 531-534. DOI. C 2011 American Society of Parasitologists. Used with permission.

Nilanjan Lodh was affiliated with The University of Vermont at the time of publication. 


\title{
Prevalence of Myxobolus cerebralis Infections Among Genetic Lineages of Tubifex tubifex at Three Locations in the Madison River, Montana
}

\author{
N. Lodh \\ Department of Biology, The University of Vermont, \\ Burlington, VT \\ L. Stevens \\ Department of Biology, The University of Vermont, \\ Burlington, VT \\ B. Kerans \\ Department of Ecology, Montana State University, \\ Bozeman, MT
}

\begin{abstract}
Host biodiversity can impact disease risk and influence the transmission of parasitic disease. Stream sediment-dwelling worms, Tubifex tubifex (Clitellata: Oligochaeta), are the definitive host of the parasite Myxobolus cerebralis (Myxozoa: Myxosporea), which causes whirling disease in salmonid fishes. Genetic diversity of $T$. tubifex is correlated with host susceptibility to $M$. cerebralis, and mitochondrial Lineage III is generally


shown to be more likely to be infected and produce the triactinomyxon (TAM) spores than other lineages. We determined the mitochondrial lineage, relative abundance, and prevalence of infection of T. tubifex collected at 3 sites in the Madison River, Montana, where previous study had shown variation in whirling disease prevalence and severity in caged trout fry. We also compared visual identification of TAMs released from cultured worms with a molecular genetic assay (diagnostic polymerase chain reaction [PCR]) for parasite detection of both infected and uninfected worms. We estimated that mitochondrial Lineage III was most abundant at the site previously shown to have high fish disease and was also most likely to be infected. The 2 techniques for detecting parasite infection did not always agree, and the likelihood of PCR $(+)$ and spore (-) was not significantly different from PCR (-) and spore $(+)$. Differences in the relative infection prevalence for these 2 lineages may explain the wide range of infection in natural streams.

Whirling disease was first described among European populations of farmed rainbow trout (Oncorhynchus mykiss), which is a native North American salmonid species that had been widely introduced into Europe and elsewhere as a food fish (Hofer, 1908). Whirling disease is caused by the Eurasian native myxozoan Myxobolus cerebralis (Mc), which first appeared in North America in the 1950s (Hoffman, 1970) and since has been reported in more than 25 states, from New York to Alaska (Bartholomew and Reno, 2002; Arsan et al., 2007). The disease has recently been recognized as the principal cause of major declines of wild rainbow trout populations in the intermountain region of the United States (Vincent, 1996).

The distribution of $M$. cerebralis and the severity of whirling disease among wild rainbow trout populations are locally and regionally variable. It is unlikely that differences in the parasite or rainbow trout host can account for all of the variation in disease severity seen in wild rainbow trout populations. Genetic variability of M. cerebralis among populations is very low (Andree et al., 1999; Whipps et al., 2004), and most rainbow trout strains differ little in their susceptibility to the triactinomyxon (TAM) spores that infect fish (Vincent, 2002). However, the distribution and abundance of $T$. tubifex, the aquatic oligochaete that serves as the definitive host of $M$. cerebralis, is a major factor in the spread, severity, and potential control of whirling disease among wild fish populations (Hedrick et al., 1998; Kerans and Stevens, 1998; Rasmussen et al., 1998, 1999; Beauchamp et al., 2005; Krueger et al., 2006). 
Tubifex tubifex exhibits considerable variability in susceptibility to the parasite. There are multiple genetic lineages (I-VI) of $T$. tubifex (Sturmbauer et al., 1999; Beauchamp et al., 2001; Crottini et al., 2008) that can be distinguished with the use of mitochondrial (16S) and genomic (18S and ITS) DNA sequences. Susceptibility of T. tubifex lineages to infection by the myxospores of $M$. cerebralis ranges from highly susceptible (Lineage III) and moderately susceptible (Lineage I), to completely resistant (Lineages V and VI; Stevens et al., 2001; Beauchamp et al., 2002; Steinbach et al., 2006; Arsan et al., 2007; Rasmussen et al., 2008). Although much of the work identifying genetic lineages of $T$. tubifex is based on the mitochondrial $16 S$ rDNA gene, it is unlikely that this gene directly confers resistance to the parasite (Arsan et al., 2007).

Because laboratory infection experiments show considerable variability in susceptibility of $T$. tubifex strains (e.g., Kerans et al., 2004), local and regional variability in whirling disease severity in rainbow trout is likely related to the particular lineage of $T$. tubifex and its density at a location (Beauchamp et al., 2005). In the Madison River, Montana, where M. cerebralis is epizootic (Vincent, 1996), whirling disease risk is positively correlated with density of infected $T$. tubifex (Krueger et al., 2006); however, studies of the mitochondrial lineages present in various habitats and their relative infection prevalence are lacking. Determining the relative abundance of genetic lineages of $T$. tubifex in the Madison River and their associated parasite prevalence can pinpoint areas to target disease control efforts. In the present study, we determined the lineages of $T$. tubifex present at 3 sites in the Madison River that had previously shown significant differences in caged trout fry infection prevalence and severity (Krueger et al., 2006) and measured the prevalence of infection with $M$. cerebralis in these worms.

Lineages of $T$. tubifex can only be distinguished based on DNA sequence (Sturmbauer et al., 1999; Beauchamp et al., 2001); however, infection with $M$. cerebralis can be detected by both visual observation of TAMs and by using a polymerase chain reaction (PCR) assay specific for M. cerebralis (Andree et al., 1998; Granath et al., 2007; Gilbert and Granath, 2008). In fish, the PCR test improved the detection of $M$. cerebralis compared to visual observation because it can detect the presence of the parasite at lower thresholds (Andree et 
al., 1998). In addition, the PCR test can confirm infected worms are producing TAMs of $M$. cerebralis and also identify worms that are infected and not yet producing TAMs (Granath and Vincent, 2010), as well as worms that may have stopped producing TAMs, but remain infected (Gilbert and Granath, 2001). For the best understanding, both methods should be used.

The present study directly compared the lineages of both infected and uninfected worms and examined infection prevalence with the use of 2 methods, i.e., visual identification of TAM production and PCR detection. To examine the role of spatial variation in the abundance of the different lineages, the following questions were addressed: (1) What is the relative abundance of different lineages of T. tubifex at various locations in the Madison River? (2) What is the parasite prevalence among different lineages? (3) Is the diagnostic PCR test equivalent to visual observation of TAMs for assessing infection?

The study locations were 3 side channels, North Slide, Pine Butte, and Lyons Bridge in the upper $39 \mathrm{~km}$ of the Madison River between Quake Lake and Ennis Lake in Madison County, Montana, where whirling disease risk had been measured in 1999 and 2000 (Krueger et al., 2006). In 2005, live oligochaetes were collected in May, June, and July with the use of kick nets, and were stored on ice for transportation to the laboratory. Specimens with hair chaetae were likely to be $T$. tubifex and were placed in 4-ml well plates with dechlorinated tap water at $15 \mathrm{C}$ on $12: 12$ light:dark light regime. For 1,253 worms, infection was determined by scanning each well for TAMs twice over a 2-wk period with the use of a dissecting microscope $(40 \times)$. We found 46 worms producing TAMs and 1,207 that were not.

After the 2-wk period, we used molecular genetic assays to test 102 worms, which included 46 worms that produced TAMs and 56 randomly selected worms that did not produce TAMs. The remaining 1,151 non- TAM producing worms were not genetically tested. DNA was extracted from these 102 worms with the use of Nucleospin ${ }^{\circledR}$ kits (BD Biosciences Clontech, Foster City, California). The DNA was used to amplify and sequence host DNA to determine the genetic lineage of T. tubifex (Sturmbauer et al., 1999) and parasite DNA was also amplified to assess the prevalence of infection for each lineage and to

Journal of Parasitology, Vol 97, No. 3 (June 2011): pg. 531-534. DOI. This article is (C) American Society of Parasitologists and permission has been granted for this version to appear in e-Publications@Marquette. American Society of Parasitologists does not grant permission for this article to be further copied/distributed or hosted elsewhere without the express permission from American Society of Parasitologists. 
examine the agreement between the PCR test for $M$. cerebralis infection and visual observation of TAMs produced by infected worms. The PCR assay also served to confirm that worms producing TAMs were infected with $M$. cerebralis and not another myxozoan. Approximately 350 base pairs (bp) of the 16S rRNA gene were sequenced to determine the mitochondrial lineage of T. tubifex with the use of previously described procedures (Beauchamp et al., 2001). The 16S rDNA sequences were then compared to sequences previously published in GenBank with the use of the NCBI BLAST algorithm, which identified the samples from this study as Lineage III and Lineage I of T. tubifex and Rhyacodrilus sp. Of the 102 worms that were tested, 61 were Lineage III, 29 were Lineage I, and 12 were Rhyacodrilus sp.

The relative abundance of the $2 T$. tubifex lineages and Rhyacodrilus sp. was variable among the 3 study locations and Lineage III was most abundant at the site that previously had highest fish disease, Lyon Bridge (likelihood ratio: $X^{2}=47.11$, df $=4, P<0.0001$; $\mathrm{JMP}^{\circledR}$ Version 8, SAS Institute, Inc., Cary, North Carolina). The relative abundance did not vary among the sampling dates (likelihood ratio: $X^{2}$ $=7.01, \mathrm{df}=4, \mathrm{P}>0.05 ; \mathrm{JMP}^{\circledR}$ Version 8, SAS Institute). Most Lineage III (40/61) worms were collected from Lyon Bridge, whereas most Lineage I (14/29) worms were from North Slide and all 12 Rhyacodrilus sp. were collected from Pine Butte (Table I). Rhyacodrilus $\mathrm{sp}$. was not included in the analysis hereafter.

Of the 46 worms that produced TAMs, 38 (83\%) were Lineage III and $8(17 \%)$ were Lineage I (Table II). In contrast, 23 (52\%) of the 44 non-TAM producing worms were Lineage III; 21 (48\%) were Lineage I. Thus, based on TAM production of field-collected worms, more Lineage III worms were producing TAMs than Lineage I worms (likelihood ratio: $X^{2}=9.723, P<0.002 ; \mathrm{JMP}^{\circledR}$ Version 8 , SAS Institute).

Forty-eight of the 90 individuals examined were positive for parasite infection by PCR (Table II). Of these, only $7(15 \%)$ were Lineage I, whereas 41 (85\%) were Lineage III. For the PCR negative worms, 22 (52\%) were Lineage I, and 20 (48\%) were Lineage III. Thus, by the PCR test, more Lineage III worms were infected than Lineage I worms (likelihood ratio: $X^{2}=15.127, P<0.0001$; $\mathrm{JMP}^{\circledR}$ Version 8, SAS Institute). 
Both ways of assessing infection showed that Lineage I worms had a lower prevalence of infection than worms of Lineage III; however, the 2 methods did not always agree. Nine individuals were scored positive by Mc diagnostic PCR and did not produce TAMs (Table III), presumably because either PCR can detect low levels of infection that cannot be detected visually, PCR can detect infection before worms start producing TAMs, or some infected worms do not produce TAMs. Eight worms produced TAMs and were not positive by Mc diagnostic PCR. Attempts to amplify and sequence the $18 \mathrm{~S}$ rDNA (Andree et al., 1998, 1999) gene were successful for 4 of these worms, which were identified as $M$. cerebralis by BLAST search algorithm (NCBI BLAST). Because all samples were PCR amplified and sequenced for $T$. tubifex lineage identification as described above, we rule out PCR inhibition. We speculate that perhaps there is another myxozoan present that fails to amplify with the genera specific primers or that the worms shed almost all of their TAMS and the infection was below the limits of PCR detection.

Lineage I showed a relatively high degree of agreement (kappa $=0.73 ; \mathrm{SE}=0.15$ ) between the PCR screen and TAM presence, whereas Lineage III had a lower degree of agreement (kappa $=0.53$, $\mathrm{SE}=0.11 ; \mathrm{JMP}^{\circledR}$ Version 8 , SAS Institute). Kappa values show the agreement of the PCR and visual observation tests $(-1=$ negative association, 0 = random, 1 = complete agreement). The symmetry for lack of agreement (Bowker Symmetry; JMP ${ }^{\circledR}$ Version 8, SAS Institute) for Lineage I was lower (0.33) than Lineage III (0.69). This test checks for symmetry in 2-way tables and the test decision is based on a $\mathrm{X}^{2}$ approximation of the distribution of the test statistic (Krampe and Kuhnt, 2007). The Bowker Symmetry is not significantly different from random $(P>0.05)$ for either lineage, indicating that PCR $(+)$ and TAM $(-)$ is as likely as PCR $(-)$ and TAM $(+)$.

Parasite susceptibility varies among $T$. tubifex lineages, but has not been directly linked to the 165 mitochondrial gene. Variation within lineages has also been documented (Beauchamp et al., 2002; Arsan et al., 2007; Rasmussen et al., 2008). Previous assessment of parasitic infection in $T$. tubifex has been done by observing TAM production (Beauchamp et al., 2002; Kerans et al., 2004, 2005; Rasmussen et al., 2008; Hallett et al., 2009) and by diagnostic PCR originally developed for fish and later used in T. tubifex (Gilbert and

Journal of Parasitology, Vol 97, No. 3 (June 2011): pg. 531-534. DOI. This article is (C) American Society of Parasitologists and permission has been granted for this version to appear in e-Publications@Marquette. American Society of Parasitologists does not grant permission for this article to be further copied/distributed or hosted elsewhere without the express permission from American Society of Parasitologists. 
Granath, 2001). More recently, qPCR was used to detect the presence of $M$. cerebralis in T. tubifex (Arsan et al., 2007). In addition, many studies (Gilbert and Granath, 2001; DuBey and Caldwell, 2004; Koel et al., 2006; Arsan et al., 2007; Baxa et al., 2008; Hallett et al., 2009; Granath and Vincent, 2010) used M. cerebralis diagnostic PCR to confirm infection in worms, which had been visually identified as TAM producers.

In laboratory experiments using worms collected from California, Montana, Utah, and Argentina, Rasmussen et al. (2008) observed higher Lineage III susceptibility in comparison to Lineage I. In comparison, Beauchamp et al. (2002) found variation between 2 locations of the Colorado River, Colorado. At 1 site, they found infection higher in Lineage I than Lineage III, whereas only Lineage III was infected at the other location. Other field observations (DuBey et al., 2004) and combined field and experimental studies (Arsan et al., 2007), show Lineage III had higher infection prevalence than Lineage I. Our investigation thus supports previous work in that it showed infection is more prevalent in Lineage III than in Lineage I, consistent with the reported higher susceptibility. Forty-one Lineage III worms (from an estimate of 614 Lineage III worms) were positive by PCR for parasitic infection, suggesting that the prevalence for Lineage III is $\sim 7 \%$, whereas only 7 Lineage I worms (from an estimated 580 Lineage I worms) were infected $(\sim 1 \%)$.

Higher prevalence for Lineage III over Lineage I in these 3 side channels of the Madison River suggest that, in a natural setting, local whirling disease prevalence is influenced by the specific lineage of $T$. tubifex present, along with other ecological and physiological parameters. These data from 2005, showing high abundance of Lineage III at Lyon Bridge, a preponderance of Lineage I at North Slide, and collection of Rhyacodrilus sp. only at Pine Butte, reflect the whirling disease risk measured with the use of sentinel cages in 19992000, where Lyon Bridge had the highest risk and Pine Butte the lowest (Krueger et al., 2006).

These results are important for management of wild fish populations because high Lineage III abundance provides more host habitat for $M$. cerebralis. Determination of site-specific contribution is important to implement small spatial scale management strategies,

Journal of Parasitology, Vol 97, No. 3 (June 2011): pg. 531-534. DOI. This article is @ American Society of Parasitologists and permission has been granted for this version to appear in e-Publications@Marquette. American Society of Parasitologists does not grant permission for this article to be further copied/distributed or hosted elsewhere without the express permission from American Society of Parasitologists. 
which may have a large impact on reducing whirling disease throughout the river system (Krueger et al., 2006).

Worm habitat variability may also play a key role in disease dynamics if different environmental tolerances and physiological parameters are also correlated with genetically based differences in susceptibility (Kerans et al., 2005). Disease can be variable among side channels and the main channel (Krueger et al., 2006) and myxospore dormancy and $T$. tubifex life span are affected by ecological phenomena, such as changes in water temperature, sedimentation, and $\mathrm{pH}$. In addition, T. tubifex can tolerate low oxygen levels, desiccation, and a wide range of temperatures (Reynoldson, 1987; Brinkhurst, 1996). However, it is still an open question with respect to the manner in which genetic differences among lineages contribute to difference in infection prevalence or determine the abundance of the lineages in different habitats.

We gratefully acknowledge L. Steinbach Elwell for collection of field materials. This material is based upon work supported by the National Science Foundation under Grant DEB-0842152 (L.S., B.L.K.) and an EPSCoR GRA (N.L.) and core faculty funding (L.S.) under Grant NSF EPS-0701410.

\section{References}

Andree, K. B., M. El-Matbouli, R. W. Hoffman, and R. P. Hedrick. 1999. Comparison of $18 \mathrm{~S}$ and ITS-1 rDNA sequences of selected geographic isolates of Myxobolus cerebralis. International Journal for Parasitology 29: 771-775.

E. Macconnell, and R. P. Hedrick. 1998. A nested polymerase chain reaction for the detection of genomic DNA of Myxobolus cerebralis in rainbow trout Oncorhynchus mykiss. Diseases of Aquatic Organisms 34: 145-154.

Arsan, E. L., S. L. Hallett, and J. L. Batholomew. 2007. Tubifex tubifex from Alaska and their susceptibility to Myxobolus cerebralis. Journal of Parasitology 93: 1332-1342.

Bartholomew, J. L., and P. W. Reno. 2002. The history and dissemination of whirling disease. In Whirling disease: Reviews and current topics, J. L. Bartholomew and J. C. Wilson (eds.). American Fisheries Society, Symposium 29, Bethesda, Maryland, p. 3-24.

Baxa, D. V., G. O. Kelley, K. S. Mukkatira, K. A. Beauchamp, C. Rasmussen, and R. P. Hedrick. 2008. Arrested development of the myxozoan parasite, Myxobolus cerebralis, in certain populations of mitochondrial $16 S$ lineage III Tubifex tubifex. Parasitology Research 102: 219-228.

Journal of Parasitology, Vol 97, No. 3 (June 2011): pg. 531-534. DOI. This article is (C) American Society of Parasitologists and permission has been granted for this version to appear in e-Publications@Marquette. American Society of Parasitologists does not grant permission for this article to be further copied/distributed or hosted elsewhere without the express permission from American Society of Parasitologists. 
Beauchamp, K. A., M. Gay, G. O. Kelley, M. El-Matbouli, R. D. Kathman, R. B. Nehring, and R. P. Hedrick. 2002. Prevalence and susceptibility of infection to Myxobolus cerebralis, and genetic differences among populations of Tubifex tubifex. Disease of Aquatic Organisms 51: 113121.

R. B. Nehring, and R. P. Hedrick. 2005. The severity of whirling disease among wild trout corresponds to the differences in genetic composition of Tubifex tubifex populations in central Colorado. Journal of Parasitology 91: 53-60.

, R. D. Kathman, T. S. Mcdowell, and R. P. Hedrick. 2001. Molecular phylogeny of tubificid oligochetes with special emphasis on Tubifex tubifex (Tubificidae). Molecular Phylogenetics and Evolution 19: 216224.

Brinkhurst, R. O. 1996. On the role of tubificid oligochaetes in relation to fish disease with special reference to the myxozoa. Annual Review of Fish Diseases 6: 29-40.

Crottini, A., R. Marotta, M. Barbuto, M. Casiraghi, and M. Feraguti. 2008. The world in a river? A preliminary analysis of the $16 \mathrm{~S}$ rDNA variability of Tubifex tubifex (Clitellata: Tubificidae) from the Lambo River. Molecular Phylogenetics and Evolution 48: 1189- 1203.

Dubey, R., and C. Caldwell. 2004. Distribution of Tubifex tubifex lineages and Myxobolus cerebralis infection in the tailwater of the San Juan River, New Mexico. Journal of Aquatic Animal Health 16: 179-185.

Gilbert, M. A., and W. O. Granath, JR. 2001. Persistent infection of Myxobolus cerebralis, the causative agent of salmonid whirling disease, in Tubifex tubifex. Journal of Parasitology 87: 101-107. and . 2008. Susceptibility of Tubifex tubifex (Annelida: Oligochaeta: Tubificidae) from the Rock Creek drainage of West central Montana, USA, to Myxobolus cerebralis (Myxozoa: Myxosporea: Myxobolidae), the causative agent of salmonid whirling disease. Comparative Parasitology 75: 92-97.

Granath, W. O., JR., M. A. Gilbert, E. J. Wyatt-Pescador, and E. R. Vincent. 2007. Epizootiology of Myxobolus cerebralis, the causative agent of salmonid whirling disease in the Rock Creek drainage of west-central Montana. Journal of Parasitology 93: 104-119.

and E. R. Vincent. 2010. Epizootiology of Myxobolus cerebralis, the causative agent of salmonid whirling disease in the Rock Creek drainage of West-Central Montana: 2004-2008. Journal of Parasitology 96: 252-257.

Hallett, S. L., H. V. Lorz, S. D. Atkinson, C. Rasmussen, L. Xue, and J. L. Bartholomew. 2009. Propagation of the myxozoan parasite Myxobolus cerebralis by different geographic and genetic populations of Tubifex

Journal of Parasitology, Vol 97, No. 3 (June 2011): pg. 531-534. DOI. This article is @ American Society of Parasitologists and permission has been granted for this version to appear in e-Publications@Marquette. American Society of Parasitologists does not grant permission for this article to be further copied/distributed or hosted elsewhere without the express permission from American Society of Parasitologists. 
NOT THE PUBLISHED VERSION; this is the author's final, peer-reviewed manuscript. The published version may be accessed by following the link in the citation at the bottom of the page.

tubifex: An Oregon perspective. Journal of Invertebrate Pathology 102: 57-68.

Hedrick, R. P., M. El-Matbouli, M. A. Adkison, and E. Macconnell. 1998. Whirling disease: Re-emergence among wild trout. Immunological Reviews 166: 365-376.

Hofer, B. 1908. Uber die drehcrankheit der regenbongenforelle. Allgemeine Fischerei-zeitung 28: 7-8.

Hoffman, G. L. 1970. Intercontinental and transcontinental dissemination and transformation of fish parasites with emphasis on whirling disease (Myxobolus cerebralis) and its effects on fish. In Special publication 5, S. F. Snieszko (ed.). American Fisheries Society, Bethesda, Maryland, p. 69-81.

Kerans, B. L., C. Rasmussen, R. Stevens, A. E. L. Colwell, and J. R. Winton. 2004. Differential propagation of the metazoan parasite Myxobolus cerebralis by Limnodrilus hoffmeisteri, Ilyodrilus templetoni and genetically distinct strains of Tubifex tubifex. Journal of Parasitology 90: 1366-1373.

and R. Stevens. 1998. Site-specific variation in population ecology of Tubifex tubifex, In Fourth whirling disease symposium: Research in progress, K. A. Beauchamp and R. P. Hedrick (eds.). Whirling Disease Foundation, Fort Collins, Colorado, p. 147-149.

, R. I. Stevens, and J. C. Lemmon. 2005. Water temperature affects a host-parasite interaction: Tubifex tubifex and Myxobolus cerebralis. Journal of Aquatic Animal Health 17: 216-221.

Koel, T. M., D. L. Mahony, K. L. Kinnan, C. Rasmussen, C. J. Hudson, S. Murica, and B. L. Kerans. 2006. Myxobolus cerebralis in native cutthroat trout of the Yellowstone Lake ecosystem. Journal of Aquatic Animal Health 18: 157-175.

Krampe, A., and S. Kuhnt. 2007. Bowker's test for symmetry and modifications within the algebraic framework. Computational Statistics and Data Analysis 51: 4124-4142.

Krueger, R. C., B. L. Kearns, E. R. Vincent, and C. Rasmaussen. 2006. Risk of Myxobolus cerebralis infection to a rainbow trout in the Madison River, Montana, USA. Ecological Applications 16: 770-783.

Rasmussen, C., A. Colwell, and J. R. Winton. 1998. Assessing relatedness of North American strains of Tubifex tubifex using the $18 \mathrm{~S}$ ribosomal RNA gene. In Fourth whirling disease symposium: Research in progress, K. A. Beauchamp and R.P. Hedrick (eds.). Whirling Disease Foundation, Fort Collins, Colorado, p. 141-145. S. Fend, B. L. Kerans, K.A. Beauchamp, A. E. L. Colwell, and J. R. Winton. 1999. Phylogenetics of tubificid worms. In Fifth whirling disease symposium: Research and management perspectives, J. C.

Journal of Parasitology, Vol 97, No. 3 (June 2011): pg. 531-534. DOI. This article is (C) American Society of Parasitologists and permission has been granted for this version to appear in e-Publications@Marquette. American Society of Parasitologists does not grant permission for this article to be further copied/distributed or hosted elsewhere without the express permission from American Society of Parasitologists. 
NOT THE PUBLISHED VERSION; this is the author's final, peer-reviewed manuscript. The published version may be accessed by following the link in the citation at the bottom of the page.

Thoesen (ed.). Whirling Disease Foundation, Missoula, Montana, p. 133-136.

J. Zickovich, J. R. Winton, and B. L. Kerans. 2008. Variability in triactinomyxon production from Tubifex tubifex populations from the same mitochondrial DNA lineage infected with Myxobolus cerebralis, the causative agent of whirling disease in salmonids. Journal of Parasitology 94: 700-708.

Reynoldson, T. B. 1987. The role of environmental factors in the ecology of tubificid oligochaetes- An experimental study. Holarctic Ecology 10: 241-248.

Steinbach, E. L. C., B. L. Kerans, C. Rasmussen, and J. R. Winton. 2006. Interactions among two strains of Tubifex tubifex (Oligochaeta: Tubificidae) and Myxobolus cerebralis (Myxozoa). Diseases of Aquatic Organisms 68: 131-139.

Stevens, R. B., B. L. Kerans, J. C. Lemmon, and C. Rasmussen. 2001. The effects of Myxobolus cerebralis myxospore dose on triactinomyxon production and biology of Tubifex tubifex from two geographic regions. Journal of Parasitology 87: 315-321.

Sturmbauer, C., G. B. Opadiya, H. Niederstatter, A. Riedmann, and R. Dallinger. 1999. Mitochondrial DNA reveals cryptic oligochaete species differing in cadmium resistance. Molecular Biology and Evolution 16: 967-974.

Vincent, E. R. 1996. Whirling disease and wild trout: The Montana experience. Fisheries 21: 32-33.

. 2002. Relative susceptibility of various salmonids to whirling disease with emphasis on rainbow and cutthroat trout. In Whirling disease: Reviews and current topics, J. L. Bartholomew and J. C. Wilson (eds.). American Fisheries Society, Symposium 29, Bethesda, Maryland, p. 109-155.

Whipps, C. M., M. El-Matbouli, R. P. Hedrick, V. Blazer, and M. L. Kent. 2004. Myxobolus cerebralis internal transcribed spacer 1 (ITS-1) sequences support recent spread of the parasite to North America and within Europe. Diseases of Aquatic Organisms 60: 105- 108.

\section{Author Affiliation}

N. Lodh, L. Stevens, and B. Kerans*, Department of Biology, The University of Vermont, 109 Carrigan Drive, 120A MLS, Burlington, Vermont 05405; *Department of Ecology, 310 Lewis Hall, Montana State University, Bozeman, Montana 59717. e-mail: nlodh@uvm.edu

Journal of Parasitology, Vol 97, No. 3 (June 2011): pg. 531-534. DOI. This article is @ American Society of Parasitologists and permission has been granted for this version to appear in e-Publications@Marquette. American Society of Parasitologists does not grant permission for this article to be further copied/distributed or hosted elsewhere without the express permission from American Society of Parasitologists. 